\title{
Evaluation of platelet indices in acute, subacute and, chronic phases of deep venous thrombosis
}

\section{Derin venöz trombozun akut, subakut ve kronik fazlarında platelet indekslerinin değerlendirilmesi}

\author{
Fatilh Ada, Vural Polat
}

Sivas Cumhuriyet University School of Medicine, Department of Cardiovascular Surgery, Sivas, Turkey

Corresponding author: Fatih Ada, MD, Sivas Cumhuriyet University School of Medicine, Department of Cardiovascular Surgery, Sivas, Turkey

E-mail: drfatihada@gmail.com

Received/Accepted: August 26, 2019 /September 28, 2019

Conflict of interest: There is not a conflict of interest.

\section{SUMMARY}

Objective: The etiology of deep vein thrombosis disease is multifactorial, and currently, it is seen as a public health problem. Simple, cheap and useful tests that can be used for diagnosis, treatment, and follow-up is increasingly needed day by day because of the increasing number of patients. For this purpose, the changes of platelet indices in routine hemogram tests during DVT follow-up were examined retrospectively.

Method: This study is a retrospective analysis of patients who diagnosed with deep venous thrombosis in Sivas Cumhuriyet University School of Medicine between 01.01.2017-31.12.2018 years. The investigation started after the decision of Sivas Cumhuriyet University Local Ethics Committee No. 2019-02/67. The acute, subacute, and chronic phase parameters of patients with deep venous thrombosis were evaluated. The study included 72 patients who developed DVT. Platelet indexes and other hemogram parameters were analyzed statistically according to the phases of deep vein thrombosis.

Results: $55.6 \%$ of the patients were female, and $44.4 \%$ were male. DVT was found most commonly in the left femoral region (48.6\%). PDW and MPV tended to increase rapidly in the acute phase of deep vein thrombosis and managed to fall in the subacute and chronic phases. However, there was no statistically significant change in platelet count and platelet crit.

Conclusions: PDW and MPV appear to be useful markers in the follow-up of all stages of deep vein thrombosis. It is evident that with the developing technology, more sensitive and specific parameters of platelet indices will be obtained.

Keywords: Deep venous thrombosis, hemogram parameters, platelet indices, mean platelet volume, the platelet distribution width

\section{Fatih Ada}

(D) Vural Polat

ORCID IDs of the authors: F.A. 0000-0002-6953-5906 V.P. 0000-0001-9553-3990

\section{ÖZET}

Amaç: Derin ven trombozu etiyolojisi multifaktöriyel bir hastalık olup günümüzde bir halk sağlığı problemi olarak görülmektedir. Artan hasta sayısıyla birlikte tanı, tedavi ve takipte kullanılabilecek basit, ucuz ve kullanışlı testlere ihtiyaç her geçen gün artmaktadır. Bu amaçla rutin hemogram testlerinde yer alan platelet indekslerinin DVT takibinde ki değişimleri retrospektif olarak incelenmiştir.

Yöntem: Bu çalıșma, 01.01.2017-31.12.2018 tarihleri arasında Sivas Cumhuriyet Üniversitesi Tıp Fakültesinde, tanı konulmuş derin venöz trombozlu hastaların retrospektif bir analizidir. Çalıșmaya, Sivas Cumhuriyet Üniversitesi Yerel Etik Kurulunun 2019-02/67sayılı kararı sonrası başlandı. Derin venöz trombozlu hastaların akut, subakut ve kronik faz 
parametreleri değerlendirildi. Çalıșmaya DVT gelișen 72 hasta dâhil edildi. Trombosit indeksleri ve diğer hemogram parametreleri derin ven trombozunun evrelerine göre istatistiksel olarak analiz edildi.

Bulgular: DVT görülen hastaların \%55,6's1 kadın ve \%44,4'ü erkek idi. En sık sol femoral bölgede $(\% 48,6)$ DVT saptanmıştır. PDW ve MPV, derin venöz trombozun akut fazında hızlı bir yükselişe geçerken subakut ve kronik fazlarda düşme eğiliminde idi. Bununla birlikte platelet sayısı ve plateletkritin istatistiksel olarak anlamlı bir değişimi yoktu.

Sonuç: Derin ven trombozun tüm evrelerinin takibinde PDW ve MPV iyi birer marker olarak görünmektedir. Gelişen teknoloji ile birlikte platelet indekslerine ait çok daha hassas ve özgül parametrelerin elde edileceği de aşikârdır.

Anahtar sözcükler: Derin venöz tromboz, hemogram parametreleri, trombosit indeksleri, ortalama trombosit hacmi, trombosit dağıllım genişliği

\section{INTRODUCTION}

Deep venous thrombosis (DVT) has symptoms in a wide range. However, sometimes it can be asymptomatic and defined as subclinical deep venous thrombosis. In addition, It may also lead to pulmonary embolism, and that can cause mortality. Untreated patients may have high morbidity such as; venous ulcer, postphlebitic syndrome. Cancer, postoperative long-term bed dependence, advanced age, obesity, smoking, organ failure, neurological diseases, hereditary causes and increased red blood cell distribution width (RDW) can have a predisposing effect in the etiology of DVT ${ }^{1}$. DVT occurs in Caucasian origin with an incidence of 50$124 / 100.000$ per year $^{2}$. There is an increasing need for innovations to be used in the prevention, diagnosis, and follow-up for deep venous thrombosis because it is so common high morbidity and mortality disease.

The aim of this study is to examine the changes of platelet indices such as platelet count, platelet crit, mean platelet volume and platelet distribution width in acute, subacute and chronic phases in the follow-up of DVT as thrombosis is the main problem in DVT so that platelet-related studies are frequently encountered ${ }^{3}$. In this study, we investigated the relationship between platelet indices of all stages of the DVT process (acute, subacute, chronic).

\section{MATERIAL AND METHODS}

In this study patients diagnosed as DVT with doppler ultrasonography between 01.01.2017 and 31.12.2018 at Sivas Cumhuriyet University included and were retrospectively evaluated. The study was started after obtaining permission from the local ethics committee of Sivas Cumhuriyet University numbered 2019-02/67. The written consent form was obtained from all patients. Demographic data such as age, sex, habits, as well as data on doppler ultrasonography and laboratory results were evaluated. Each patient was classified as acute (first 2 weeks), subacute (2-4 weeks), and chronic (after 4 weeks). The course of the platelet indices, as well as the white blood cell count, hemoglobin level, and the percentage of hematocrit, were analyzed. The patients bigger than 18 years of age as diagnosed of deep vein thrombosis with venous Doppler ultrasonography which complete blood count analysis test was performed in Sivas Cumhuriyet University Hemogram device, were included study. Patients who did not have a hemogram test in all three periods, patients who had a diagnosis and had their hemogram test performed at the external center, and patients under 18 years of age were excluded from the study.

\section{Statistical Analysis:}

Statistical analysis was performed using the SPSS (version 24.0, StataCorp LP, College Station, TX, USA) software package. Continuous variables were expressed as mean \pm standard deviation (mean \pm SD), and categorical variables were expressed as a percentage (\%).One-Way Anova test was used to test homogeneity of the variables. According to this test result, the Tukey test was performed.However, the Games-Howell test was conducted as the homogeneity of the variables of MPV values was $\mathrm{P}<0.05 . \mathrm{P}$ value $<.05$ was considered as statistically significant in Tukey and Games-Howell tests.

\section{RESULTS}

Between 01.01.2017 and 31.12.2018, 481 patients were diagnosed as DVT by doppler ultrasonography at Sivas Cumhuriyet University. However, 72 patients who met inclusion criteria were included in the study. $55,6 \%$ of the patients were female, $44,4 \%$ were male, and the mean age was $56,2 \pm 20,3$ years. In it's etiology, cases with cancer were seen as $27,8 \% \quad(n=20)$, while postpartum DVT was as $9,7 \%(\mathrm{n}=7)$ (Table 1). DVT seen most commonly in the left femoral region and less in the right iliac region in the lower extremity (Table 2). The DVT rates were equal in the upper extremity. In hemogram parameters, PDW showed a statistically significant difference in all stages of DVT. MPV was significant between acute and chronic stages. No statistically significant difference was found in any of the other parameters (Table 3 ). 
Table 1: Demographic Data of the patients. (DVT: Deep venous thrombosis)

\begin{tabular}{lcl}
\hline Demographic Data & $\begin{array}{c}\text { Percentage (\%) } \\
\text { or Mean }(\overline{\mathbf{x}}+\mathbf{s d})\end{array}$ & (n) or min-max \\
\hline Male & 44,4 & 32 \\
Female & 55,6 & 40 \\
Age & $56,2 \pm 20,3$ & $18-89$ \\
Tobacco use & 37,5 & 27 \\
Diabetes Mellitus & 34,7 & 25 \\
Hypertension & 40,3 & 29 \\
Chronic renal disease & 16,7 & 12 \\
Chronic obstructive pulmonary disease & 22,2 & 16 \\
Surgical history & 34,7 & 25 \\
Oral contraceptive use & $\mathbf{1 3 , 9}$ & $\mathbf{1 0}$ \\
Cancer & $\mathbf{2 7 , 8}$ & $\mathbf{2 0}$ \\
Genetic predisposition & $\mathbf{1 6 , 7}$ & $\mathbf{1 2}$ \\
Postpartum DVT & $\mathbf{9 , 7}$ & $\mathbf{7}$ \\
\hline
\end{tabular}

Table 2: Region of the DVT. (DVT: Deep venous thrombosis)

\begin{tabular}{lcc}
\hline Region of the DVT & Percentage (\%) & (n) \\
\hline Left popliteal & 15,3 & 11 \\
Left femoral & 48,6 & 35 \\
\hline Left iliac & $\mathbf{4 , 2}$ & $\mathbf{3}$ \\
Right popliteal & $\mathbf{8 , 3}$ & $\mathbf{6}$ \\
Right femoral & $\mathbf{1 8}$ & $\mathbf{1 3}$ \\
Right iliac & $\mathbf{2 , 7}$ & $\mathbf{2}$ \\
Left axillary & $\mathbf{1 , 4}$ & $\mathbf{1}$ \\
Right axillary & $\mathbf{1 , 4}$ & $\mathbf{1}$ \\
\hline
\end{tabular}


Table 3: The result of hemogram parameters. (A-S: Acute-Subacute, A-C: Acute-Chronic, S-C: SubacuteChronic, SD: standard deviation)

\begin{tabular}{|c|c|c|c|c|}
\hline \multirow[t]{2}{*}{ Parameters } & $\begin{array}{c}\text { Acute Phase } \\
(\mathrm{n}=72)\end{array}$ & $\begin{array}{c}\text { Subacute Phase } \\
(\mathrm{n}=72)\end{array}$ & $\begin{array}{c}\text { Chronic Phase } \\
(\mathrm{n}=72)\end{array}$ & \multirow[t]{2}{*}{$\mathbf{P}$} \\
\hline & \multicolumn{3}{|c|}{ Mean \pm SD } & \\
\hline $\begin{array}{l}\text { White blood cell } \\
\left(\mathrm{WBC} \times 10^{9} / \mu \mathrm{l}\right)\end{array}$ & $11,1507 \pm 6.85$ & $10,4967 \pm 15.6$ & $10,5922 \pm 19.1$ & $\begin{array}{l}\text { A-S } 0,962>0,05 \\
\text { A-C } 0,972>0,05 \\
\text { S-C } 0,999>0,05\end{array}$ \\
\hline $\begin{array}{l}\text { Hemoglobin } \\
\text { (g/dL) }\end{array}$ & $12,6917 \pm 2.49$ & $12,3183 \pm 2.44$ & $12,7014 \pm 2.41$ & $\begin{array}{l}\text { A-S } 0,632>0,05 \\
\text { A-C } 1,000>0,05 \\
\text { S-C } 0,617>0,05\end{array}$ \\
\hline Hematocrit (\%) & $39,0250 \pm 7.22$ & $38,2111 \pm 6.92$ & $39,2375 \pm 6.99$ & $\begin{array}{l}\text { A-S } 0,768>0,05 \\
\text { A-C } 0,982>0,05 \\
\text { S-C } 0,658>0,05\end{array}$ \\
\hline $\begin{array}{c}\text { Platelet (PLT } \times \\
\left.10^{9} / \mu \mathrm{l}\right)\end{array}$ & $221,8347 \pm 107$ & $266,5972 \pm 136$ & $247,9722 \pm 107$ & $\begin{array}{l}\text { A-S } 0,062>0,05 \\
\text { A-C } 0,382>0,05 \\
\text { S-C } 0,612>0,05\end{array}$ \\
\hline $\begin{array}{c}\text { Plateletcrit (PCT } \\
\%)\end{array}$ & $0,2134 \pm 0.09$ & $0,2448 \pm 0.12$ & $0,2291 \pm 0.10$ & $\begin{array}{l}\text { A-S } 0,179>0,05 \\
\text { A-C } 0,647>0,05 \\
\text { S-C } 0,648>0,05\end{array}$ \\
\hline $\begin{array}{c}\text { Mean Platelet } \\
\text { Volume (MPV } \\
\text { fL) }\end{array}$ & $9,7778 \pm 1.29$ & $9,3083 \pm 1.19$ & $9,2486 \pm 0.96$ & $\begin{array}{l}\text { A-S } 0,065>0,05 \\
\text { A-C } \mathbf{0 , 0 1 7}<\mathbf{0 , 0 5} \\
\text { S-C } 0,942>0,05\end{array}$ \\
\hline $\begin{array}{c}\text { Platelet } \\
\text { Distribution } \\
\text { Width (PDW \%) }\end{array}$ & $16,3361 \pm 0.43$ & $15,9597 \pm 0,37$ & $15,7153 \pm 0.38$ & $\begin{array}{l}A-S 0,000<0,05 \\
A-C 0,000<0,05 \\
S-C 0,001<0,05\end{array}$ \\
\hline
\end{tabular}

\section{DISCUSSION}

Nowadays, deep vein thrombosis is accepted as a public health problem. Venous thromboembolism or it's most common form DVT is a significant cause of mortality and morbidity ${ }^{4}$. This disease, which occurs at a rate of $1 \%$ in older ages, is most commonly seen in lower extremities and pelvic veins in developed countries ${ }^{5}$. Platelet activation is essential for the development of thrombosis. MPV and PDW increases during platelet activation. However, PDW is more specific than MPV in demonstrating platelet activation ${ }^{6}$. Indeed, the data we obtained from our study supports this. The platelet count begins to decrease due to platelet use during thrombosis process. This promotes the stimulation of bone marrow megakaryocytes by thrombopoietin and accelerates the production of hyperlobulated, more giant platelets with higher DNA content. Therefore, platelets with high MPV are seen in destructive thrombocytopenia because of megakaryocytic stimulation ${ }^{7}$. In thrombocytopenic patients, the splenic pool undergoes destruction and thus an increase in PDW ${ }^{8}$. The rise in PDW and MPV may be independent of platelet count. Indeed, in patients with myeloproliferative thrombocytosis, PDW was found to be over $17 \%$. Especially in this patient group, PDW value can be observed as high, while the platelet count is normal ${ }^{9}$. Osselaer and colleagues attributed this increase to changes in platelet membrane and adenosine nucleotide content ${ }^{10}$.

It is tough to actually make a standardization for the platelet and its indices, which are the subject of many studies. Because there are many parameters that determine the value of this index. For example, the way of blood sampling, temperature, waiting time and the effect of the anticoagulants used so that it is challenging to talk about a standardization 11 .

There are a lot of studies in the literature on total platelet indices or particularly platelet indices in various disease groups. In addition, indices such as $\mathrm{MPV} /$ platelet ratio, neutrophil/lymphocyte ratio, leukocyte/ lymphocyte ratio are used for many different disease groups or treatment methods ${ }^{12}$. From these studies, Han and colleagues found that the increased rate of MPV and MPV/Platelet count correlated with DVT ${ }^{2}$. It is a known fact that DVT is associated with many diseases. Wang et al. found that PDW was significantly increased in patients with chronic obstructive pulmonary disease 
(COPD) and pulmonary embolism ${ }^{13}$. The source of $70 \%$ of pulmonary embolism is DVT ${ }^{14}$. However, all DVT doesn't result as pulmonary embolism. Sevük and colleagues reported that the higher MPV and PDW in acute DVT shows a more elevated risk of pulmonary embolism ${ }^{15}$.

There are many publications about the use of PDW as a diagnostic or follow-up marker. One of these is the study of Vatankulu and colleagues showed the relationship between PDW elevation and total occlusive coronary artery disease ${ }^{16}$. On the other hand, Adam and his colleagues demonstrated the correlation between the PDW elevation and the degree of carotid artery stenosis ${ }^{17}$. Li et al. found the high PDW level was associated with increased mortality in melanoma ${ }^{18}$. Bhanukumar et al. showed that patients with type $2 \mathrm{DM}$ without a proven history of thrombosis had significantly higher PDW than the control group. They explained the increased amount of thrombosis with PDW elevation and emphasized that PDW value should be considered in diabetic patients for follow-up ${ }^{19}$. Sevuk et al. investigated PDW value in different patient groups. They noted that this value decreased in chronic DVT while it had a high value in acute DVT. They emphasized that a reduction in PDW value was a predictor for complete DVT resolution ${ }^{20}$. Bolayir and colleagues in study of the place of MPV, PDW and platelet / lymphocyte ratio in cerebral venous thrombosis, they observed that MPV and PDW increased significantly in thrombosis group ${ }^{21}$. Kamisli et al. also reported that PDW and MPV values had risen considerably in the early phase of cerebral venous sinus thrombosis compared to the control group 22 .

Fan and colleagues found high rates of MPV and PDW in acute gangrenous appendicitis ${ }^{23}$. Almost all of the publications in the literature mention situations associated with increased MPV and PDW. However, Kaplanoglu et al. found a significant relationship between decreased PDW and spontaneous abortion ${ }^{24}$.

Ege et al. performed coronary angiography for various reasons and showed that PDW values were higher in patients with coronary artery bypass graft and in patients with saphenous vein graft occlusion than in the patent group ${ }^{25}$. In the study of Akbulut and colleagues, it was shown that MPV value increased and platelet count decreased in patients with acute myocardial infarction ${ }^{26}$.

Willians and colleagues examined the full blood parameters in groups of patients with DVT and new diseases.Contrary to classical belief, they found PDW increased while MPV was normal in DVT ${ }^{3}$.
The relationship between MPV increase and thrombosis status is also discussed in the literature. As a matter of fact, Cil et al. have shown that MPV value is high in patients developing DVT. They also found that this elevation correlated with bodymass index, smoking frequency, hematocrit, and platelet count ${ }^{27}$. Looking for answers to the question of whether complete blood parameters have a correlation in themselves, Wiwanitkit and his colleagues have shown that only RDW and PDW correlate with each other ${ }^{4}$. The first step of diagnostic processes following clinical suspicion is the examination of colored doppler ultrasonography. D-Dimer and fibrinogen are used to support the diagnosis. In the study of Huang et al., high MPV and PDW level were associated with pulmonary embolism. In particular, the simultaneous elevation of D-Dimer and MPV level was found to have $90,9 \%$ specificity in pulmonary embolism ${ }^{28}$. After definitive diagnosis, the underlying acquired and genetic factors should be investigated simultaneously with the treatment ${ }^{18}$. Medical, interventional and surgical methods are included in the procedure. It is possible to prevent mortality and morbidity due to DVT with a timely and correct treatment ${ }^{14}$. In the follow-up, colored doppler ultrasonography is frequently used.

\section{CONCLUSION}

PDW has been found to be a cheap, simple, and useful marker for monitoring all phases of DVT. It can be used as an adjunct test to diagnose acute DVT and to follow the chronic process. In addition, a new PDW elevation may suggest recurrence in patients with chronic DVT. MPV appears to be useful in differentiating between acute and chronic DVT. It does not seem to be significant for subacute DVT.

\section{REFERENCES}

1. Cay N, Unal O, Kartal MG, Ozdemir M, Tola M. Increased level of red blood cell distribution width is associated with deep venous thrombosis. Blood Coagul. Fibrinolysis 2013;24(7):727-31.

2. Han JS, Park TS, Cho SY, Joh JH, Ahn HJ. Increased mean platelet volume and mean platelet volume/platelet count ratio in Korean patients with deep vein thrombosis. Platelets 2013;24(8):590-3.

3. Willans DJ, Mill SC, Ranney EK. Common thrombotic disorders defined by $\mathrm{CBC}$ platelet parameters. Clin. Appl. Thromb. Hemost.1995;1(3):188-201. 
4. Wiwanitkit, V. Plateletcrit, mean platelet volume, platelet distribution width: its expected values and correlation with parallel red blood cell parameters. Clin. Appl. Thromb. Hemost.2004;10(2):175-8.

5. Wakefield TW, Myers DD, Henke PK. Mechanisms of venous thrombosis and resolution. Arterioscler. Thromb. Vasc. Biol.2008;28(3):387-91.

6. Vagdatli E, Gounari E, Lazaridou E, Katsibourlia E, Tsikopoulou F, Labrianou I. Platelet distribution width: a simple, practical and specific marker of activation of

coagulation. Hippokratia 2010;14(1):2832.

7. Beyan C. Is mean platelet volume a predictive marker in patients with venous thrombosis?. Clin. Appl. Thromb. Hemost. 2012;18(6):670-1.

8. Reddy RS, Khan MI, Phansalkar MD. Platelet Distribution Width (PDW) in Thrombocytopenia. Indian Medical Gazette May 2015;169-174.

9. Van der Lelie J, Von dem Borne AK. Platelet volume analysis for differential diagnosis of thrombocytosis. J. Clin. Pathol. 1986;39(2):129-33.

10. Osselaer JC, Jamart J, Scheiff JM. (1997). Platelet distribution width for differential diagnosis of thrombocytosis. Clin. Chem. 1997;43(6):1072-6.

11. Farias $M G$, Schunck EG, Dal Bó $S$, de Castro SM. Definition of reference ranges for the platelet distribution width (PDW): a local need. Clin. Chem. Lab. Med. 2010;48(2):255-7.

12. Aldemir M, Pektaş MB, Parlar Aİ, Akcı Ö, Emren SV, Tecer E, et al. L-carnitine supplementation reduces short-term neutrophil-lymphocyte ratio in patients undergoing coronary artery bypass grafting. Int J Surg 2015;100(7):1160-8.

13. Wang M, Zhang J, Ji Q, Yang Q, Zhao F, $\mathrm{Li} \mathrm{W}$, et al. Evaluation of platelet distribution width in chronic obstructive pulmonary disease patients with pulmonary embolism. J Biomark.2016;10(6):587-96.

14. Sarıül A, Tanyeli Ö. Derin ven trombozunda güncel tedavi yaklaşımları. Turk Gogus Kalp Dama 2007;15(4):316-21.

15. Sevuk U, Bahadir MV, Altindag R, Baysal E, Yaylak B, Ay N, et al. Value of serial platelet indices measurements for the prediction of pulmonary embolism in patients with deep venous thrombosis. Ther Clin Risk Manag2015;11:1243-9.

16. Vatankulu MA, Sonmez O, Ertas G, Bacaksiz A, Turfan M, Erdogan E, et al. A new parameter predicting chronic total occlusion of coronary arteries: platelet distribution width. Angiology2014;65(1):60-4.

17. Adam G, Kocak E, Özkan A, Reşorlu M, Çınar C, Bozkaya H, et al. Evaluation of platelet distribution width and mean platelet volume in patients with carotid artery stenosis. Angiology 2015;66(4):375-8.

18. Li N, Diao Z, Huang X, Niu Y, Liu T, Liu $\mathrm{ZP}$, et al. Increased platelet distribution width predicts poor prognosis in melanoma patients. Scientific reports, 2017;7(1):2970.

19. Bhanukumar M, Ramaswamy PKH, Peddi NK, Menon WB. Mean Platelet Volume and Platelet Distribution Width as Markers of Vascular Thrombosis in Type 2 Diabetes Mellitus. J Postgrad Med Edu Res 2016;50(3):127-131.

20. Sevuk U, Altindag R, Bahadir MV, Ay N, Demirtas E, Ayaz F. Value of platelet indices in identifying complete resolution of thrombus in deep venous thrombosis patients. Indian J Hematol Blood Transfus 2015;31(1):71-6.

21. Bolayır A, Gökçe ŞF. The role of mean platelet volume, platelet distribution width and platelet/lymphocyte ratio in development of cerebral venous thrombosis. Cumhuriyet Med J 2017;39(4):683-91.

22. Kamisli O, Kamisli S, Kablan Y, Gonullu $\mathrm{S}$, Ozcan C. The prognostic value of an increased mean platelet volume and platelet distribution width in the early phase of cerebral venous sinus thrombosis. Clin. Appl. Thromb. Hemost. 2013;19(1):29-32.

23. Fan Z, Pan J, Zhang $Y$, Wang Z, Zhu M, Yang $B$, et al. Mean platelet volume and 
platelet distribution width as markers in the diagnosis of acute gangrenous appendicitis. Dis Markers. 2015;2015:542013.

24. Kaplanoglu M, Yuce T, Bulbul M. (2015). Decreased mean platelet volume is associated with the developing stage of fetoplacental unit in spontaneous abortion. Int J Clin Exp Med2015;8(7):11301-6.

25. Ege MR, Guray U, Guray Y, Acıkgoz S, Demirkan B. Platelet distribution width and saphenous vein disease in patients after CABG. Herz 2013;38(2):197-201.
26. Akbulut N, Yıldız M, Yıldız BŞ, Aktaş S, Yaylacı M. Akut Miyokard İnfarktüslü Hastalarda Ortalama Trombosit Hacmi ve Trombosit Sayısının Değerlendirilmesi. MN kardiyoloji 2006;13(3):180-185.

27. Çil H, Yavuz C, İslamoğlu Y, Tekbaş EÖ, Demirtaş S, Atılgan ZA, et al. Platelet count and mean platelet volume in patients with in-hospital deep venous thrombosis. Clin. Appl. Thromb. Hemost. 2012;18(6):650-3.

28. Huang J, Chen $Y$, Cai $Z$, Chen $P$. Diagnostic value of platelet indexes for pulmonary embolism. Am J Emerg Med2015;33(6):760-3. 